\title{
ANALIZA PRAWNO-LINGWISTYCZNA USTAW O REJESTROWANYCH ZWIAZZKACH PARTNERSKICH W NIEMCZECH, AUSTRII I SZWAJCARII
}

\author{
Józef JAROSZ, dr \\ Instytut Filologii Germańskiej, Uniwersytet Wrocławski \\ pl. Biskupa Nankiera 15, 50-140 Wrocław \\ jozef.jarosz@uni.wroc.pl
}

\begin{abstract}
Abstrakt: Od 1 stycznia 2010 roku obowiązuje w Austrii nowe prawo o rejestrowanych związkach partnerskich osób tej samej płci. Jest to trzecia ustawa niemieckojęzyczna, która wprowadza nowy porządek prawny $\mathrm{w}$ tej dziedzinie życia społecznego w kolejnym kraju niemieckiego obszaru językowego. Celem artykułu, który z założenia jest badaniem prawnoporównawczym i wpisuje się w nurt badań komparatystyki prawniczej, będzie analiza wspomnianych aktów legislacyjnych przeprowadzana z dwóch perspektyw. Przedmiotem porównania jest nie tylko instytucja związku partnerskiego, ale również struktura przedmiotowych ustaw oraz od strony językowej: terminologia specjalistyczna odnosząca się do przedmiotu ustaw rozpatrywana również w aspekcie przekładoznawczym. Wyniki badania dostarczą odpowiedzi, na ile rozwiązania legislacyjne zaproponowane przez ustawodawców trzech krajów w podobny sposób regulują ten sam fragment rzeczywistości społecznej i mogą uchodzić za standardowe. Analiza językowa wskaże na obecność lub brak specjalnej terminologii oraz jej homogeniczność bądź narodową (regionalną) wariantywność na obszarze państw niemieckojęzycznych.
\end{abstract}

\section{SPRACHLICHE UND RECHTSVERGLEICHENDE ANALYSE DER GESETZE ÜBER DIE EINGETRAGENE PRATNERSCHAFT IN DEUTSCHLAND, ÖSTERREICH UND IN DER SCHWEIZ}

\begin{abstract}
Abstrakt: Am 1. Januar 2010 trat das Eingetragene Partnerschaft-Gesetz (EPG) in Österreich in Kraft. Es ist das dritte deutschsprachige Land, in dem der Bereich des öffentlichen Lebens gesetzlich geregelt wird. Die in dem vorliegenden Artikel dargestellte rechtsvergleichende Untersuchung setzt sich zum Ziel die drei deutschsprachigen Gesetzestexte miteinander aus zwei Perspektiven zu vergleichen. Den Ausgangspunkt bilden zum einen die Bestimmungen hinsichtlich des Rechtsinstituts der eingetragenen Lebenspartnerschaft und die von den Gesetzgebern vorgeschlagenen rechtlichen Lösungen. Zum anderen umfasst die Vergleichsbasis die sprachliche Ebene der Texte. Sie werden nämlich hinsichtlich der Fachterminologie untersucht, und somit wird es der Frage nachgelaufen, ob die vorgefundenen Fachtermini ein homogenes Repertoire darstellen oder eher als nationale (regionale) Varianten im deutschsprachigen Raum anzusehen sind. Weniger Augenmerk wird der äußeren Struktur der Gesetzestexte gewidmet. Die Untersuchung schließen einige Überlegungen und Bemerkungen aus dem übersetzungswissenschaftlichen Standpunkt ab.
\end{abstract}




\section{LINGUISTIC AND LEGAL ANALSIS OF ACTS ON REGISTERED CIVIL UNIONS IN GERMANY, AUSTRIA AND SWITZERLAND}

A new law on registered civil unions of persons of the sme sex has been in force in Austria since 1 January 2010. It is the third statute which introduces a new legal order in this sphere of social life in a German-speaking country. The main aim of this paper is to compare the above mentioned legal acts from a legal and linguistic perspective. The analysed terminology will also be investigated in the aspect of translation. The results of the research will show similities and differences between institutions introduced in the dicussed legal systems and reveal national (regional) terminological usage.

\section{Wprowadzenie}

Przemiany $\mathrm{w}$ społeczeństwie oraz zmiany $\mathrm{w}$ prawie pozostają $\mathrm{w}$ stosunku do siebie $\mathrm{z}$ perspektywy diachronicznej - w dwóch relacjach ${ }^{19}$ : (1) prawo kreuje nowy porządek społeczny i jest źródłem nowych zachowań, (2) zmiany w społeczeństwie wymuszają na prawodawcy ujęcie nowych zjawisk, postaw, będących faktami społecznymi, w ramy norm prawnych, tj. prawo, jako byt sekundarny, podąża za rozwojem społeczeństwa ${ }^{20}$. Geneza analizowanych w niniejszym artykule aktów prawnych wpisuje się w drugi scenariusz: zmieniająca się obyczajowość, rozmiary tych zmian oraz potrzeba społeczna stały się bodźcem i impulsem do skodyfikowania ich w postaci ustaw będących produktem procesu decyzyjnego toczącego się w ramach odpowiednich grup społecznych czy całych społeczeństw. Niewątpliwie państwo może sprzyjać określonym przeobrażeniom stosunków społecznych, a inne utrudniać. W szczególności może ono wprowadzać unormowania kreujące nowe instytucje prawne odpowiadające potrzebom społeczeństwa na danym etapie rozwoju oraz tworzyć nowe struktury organizacyjne życia społecznego. Tworząc i stosując prawo, państwo realizuje swoje funkcje władcze (Korycki et al. 2008, 23). Realne istnienie (obowiązywanie) omawianych uregulowań prawnych uzależnione jest od społecznego przyzwolenia dla prawa, tzn. od tego, w jakim stopniu członkowie społeczeństwa są gotowi przestrzegać je i sankcjonować. Doniosłość problemu oraz rozmiary zjawiska $\mathrm{w}$ wielu społeczeństwach pozwalają przewidzieć dynamikę zmian w przedmiotowym zakresie w innych krajach w najbliższej przyszłości.

Problematyka związków partnerskich i małżeństw homoseksualnych jest jeszcze nowym zjawiskiem i to zarówno w sferze obyczajowej, jak i praktyki legislacyjnej. Cytowane w tytule ustawy świadczą niezbicie o próbie dostosowania stanu prawnego do współczesnych przemian i aktualnego stanu wiedzy o seksualności człowieka. Dezyderatem współczesnej seksuologii jest zrewidowanie nastawienia do zjawiska homoseksualizmu, które w ujęciu wielu specjalistów nie jest przejawem choroby, lecz wrodzoną lub nabytą cechą ${ }^{21}$. Takie ujęcie problemu stało się przesłanką do ukształtowania się poglądu (jednego z wielu), zgodnie z którym homoseksualizm nie powinien podlegać ocenom w kategoriach moralnych, ponieważ jest to jedna z postaci

\footnotetext{
${ }^{19}$ Teoretycy prawa określają wzajemne zależności prawa i państwa jako związki funkcjonalne (Korycki et al. 2008, 23).

${ }^{20}$ Chodzi oczywiście o prawo pozytywne, które w odróżnieniu od prawa naturalnego, zależne jest od władzy państwowej (Redelbach 1998, 108).

${ }^{21}$ Przełom w podejściu do zjawiska homoseksualizmu stanowiła decyzja Amerykańskiego Towarzystwa Psychiatrycznego (American Psychiatric Association), zgodnie z którą w roku 1973 homoseksualizm skreślono z listy chorób (Dannecker 2000, 341).
} 
życia seksualnego ${ }^{22}$. Z drugiej zaś strony wprowadzenie uregulowań prawnych w zakresie usankcjonowania związków osób tej samej płci wywołuje często sprzeciwy i protesty obywateli o poglądach konserwatywnych ${ }^{23}$. Niekiedy brak przyzwolenia społecznego sprawia, że nie pojawia się inicjatywa ustawodawcza lub opracowanym projektom ustaw nie zostaje nadany bieg legislacyjny, jak to miało miejsce w Polsce ${ }^{24}$. Oponenci tego typu rozwiązań legislacyjnych są zdania, że usankcjonowanie prawne związków osób tej samej płci osłabi pozycję rodziny i doprowadzi do zezwolenia małżeństwom homoseksualnym na adopcję, co jest sprzeczne z ogólnie przyjętym uzusem społecznym i zasadami religii.

Usankcjonowanie prawem związków partnerskich jest nowym zjawiskiem w prawodawstwie światowym. Najstarsze uregulowania miały miejsce w Skandynawii w latach 80-tych i 90-tych dwudziestego wieku ${ }^{25}$. W krajach niemieckiego obszaru językowego ${ }^{26}$ rozwiązania prawne datują się na początek bieżącego stulecia: Niemcy 2001, Szwajcaria 2007, Austria 2010. Ich porównanie będzie przedmiotem dalszych rozważań w niniejszym artykule. Konfrontacja ustaw nastąpi w ujęciu formalnym (struktura) oraz w ujęciu materialnym (treść) ze specjalnym uwzględnieniem cech specyficznych leksyki. Chodzi m.in. o wykazanie spójności wzgl. odrębności terminologicznej $\mathrm{w}$ dokumentach $\mathrm{w}$ jednym języku $\mathrm{w}$ trzech krajach. Przedmiotowe porównanie instytucji prawnej $\mathrm{w}$ trzech krajach następuje zgodnie $\mathrm{z}$ przesłankami metodologicznymi komparatystyki prawniczej (Tokarczyk 2008, 35).

\section{Ustawy o rejestrowanych związkach na tle systemu legislacyjnego - charakterystyka ogólna}

Terminem zarejestrowany zwiazek partnerski (nazywany też formalnym zwiazkiem partnerskim) określa się zwykle usankcjonowany prawem związek cywilny dwóch osób. We wszystkich trzech ustawach prawodawca jednoznacznie i zgodnie definiuje uczestników związku: osoby tej samej płci ${ }^{27}$. W szczególności rejestrowany związek partnerów tej samej płci nie jest tym samym co małżeństwo osób tej samej płci (gleichgeschlechtliche Ehe $)^{28}$. W rozumieniu prawa krajów, z których pochodzą analizowane teksty, małżeństwo i rejestrowany związek partnerski nie stanowią

\footnotetext{
${ }^{22}$ Takie ujęcie problemu przedstawił m.in. amerykański biolog Alfred Kinsey (1894-1956), (por. Köllner 2001, 186).

${ }^{23}$ Pogląd na charakter dyskursu konserwatywnego wprzedmiotowym zakresie daje m.in. artykuł Wojciecha Sadurskiego (2011).

${ }^{24}$ Według mojej wiedzy przedmiotowa problematyka doczekała się dwóch projektów ustaw: autorstwa senator Marii Szyszkowskiej (2004) oraz senackiego projektu ustawy z dnia 3 grudnia 2004 r.

${ }^{25}$ Dania (1989), Norwegia (1993), Szwecja (1995), Islandia (1996), Holandia (1998), Finlandia (2002), por. (Botschaft 2002, 8).

${ }^{26}$ Analiza nie obejmuje sytuacji prawnej w niemieckojęzycznej części społeczeństwa Belgii, Luxemburga i Liechtensteinu.

${ }^{27} \mathrm{~W}$ niemieckim żargonie prawniczym instytucja ta znana jest również pod nazwą die Hamburger Ehe (,hamburskie małżeństwo'). Nazwa wywodzi się z hamburskiej ustawy o związkach tej samej płci, która była poprzedniczką dzisiejszej ustawy o związkach partnerskich w Niemczech.

${ }^{28}$ Instytucja prawna tego typu obowiązuje m.in. w Belgii, Holandii i Hiszpanii.
} 
tożsamych instytucji, tzn. są odrębnymi bytami prawnymi ${ }^{29}$. Potoczne rozumienie utożsamia obydwa związki, co jest źródłem sprzeciwów, protestów i ostrej krytyki związków partnerskich.

Uchwalenie ustawy o związkach partnerskich tej samej płci zmierza do zrównania ludzi pod względem przysługujących im praw seksualnych ${ }^{30}$ niezależnie od ich orientacji seksualnej. Ma więc na celu dostosowanie stanu prawnego do wymogów i oczekiwań społeczeństwa, jakim powinno odpowiadać nowoczesne państwo demokratyczne, tj.: poszanowania wolności człowieka, pluralizmu światopoglądowego i tolerancji. W społeczeństwie demokratycznym nie powinno być miejsca na dyskryminację jakichkolwiek mniejszości, jeżeli swoją działalnością nie naruszają one ustalonego porządku prawnego i zasad współżycia społecznego (Botschaft 2002,4). Omawiane akty prawne realizują per se całą paletę funkcji prawa. Pojawienie się nowych uregulowań legislacyjnych w państwie jest przejawem funkcji dynamizującej (innowacyjnej). W zasadniczy sposób zmienia ono zastane układy stosunków społecznogospodarczo-politycznych. Sprzyja kreowaniu i rozwojowi form życia społecznego form nowych lub takich, które dotychczas nie istniały lub miały marginalne znaczenie. Centralne znaczenie ma funkcja ochronna ze szczególnym uwzględnieniem funkcji opiekuńczej (Redelbach 1998, 117), co w odniesieniu do badanych dokumentów oznacza, że treść norm ma zapewnić m.in. prawną ochronę określonym dobrom, a przede wszystkim prawną ochronę podmiotom tworzącym rejestrowane związki partnerskie ${ }^{31}$. $\mathrm{Z}$ pewnością nie można odmówić omawianym dokumentom funkcji wychowawczej. Jej ideą jest wprowadzanie w życie wzorców postaw, kształtowanie tych postaw, którym adresaci norm prawnych powinni okazywać posłuch (Redelbach 1998, 118). Prawo o związkach partnerskich obejmuje część systemu prawnego, którego elementem jest prawo rodzinne. To zaś reguluje najważniejsze $\mathrm{z}$ wykształconych na danym etapie rozwoju społecznego więzi między podmiotami danego społeczeństwa. Niektóre uregulowania w zakresie skutków prawnych rejestrowanych związków partnerskich są podobne do tych, które odnoszą się do instytucji małżeństwa. Struktura normy prawnej zakłada zwykle współwystępowanie trzech części: hipotezy, dyspozycji i sankcji. Hipoteza utożsamia sytuację, w której norma prawna znajduje zastosowanie. Dyspozycja to część normy prawnej, która implikuje modelowy sposób zachowania. Sankcja werbalizuje, jakie ujemne skutki pociagnie za sobą niezastosowanie się do dyspozycji (Redelbach 1998, 140). Część oczekiwanych przez legislatora zachowań podmiotów stosunków prawno-rodzinnych ujętych w prawie o związkach partnerskich regulowanych jest jedynie $\mathrm{w}$ formie postulatywnej, tj. bez możliwości ich skutecznego wyegzekwowania ze

\footnotetext{
${ }^{29}$ W nieco dowcipny, ale jednoznaczny sposób odżegnują się od instytucji małżeństwa homoseksualnego austriaccy ustawodawcy w rządowym komentarzu do ustawy o związkach partnerskich: „Nach ihren Wirkungen ist die eingetragene Partnerschaft keine Ehe light und auch keine Schmalspurehe. Zwecks Abgrenzung der Ehe von der eingetragenen Partnerschaft soll nicht der Weg von Verweisungen zum geltenden Eherecht gewählt werden, sondern die entsprechenden zivilrechtlichen Regelungen über die wechselseitigen Rechte und Pflichten in einem eigenen Sondergesetz zusammengefasst werden“ (por. Erläuterungen 2009, 3).

${ }^{30}$ Listę praw seksualnych zawiera Powszechna Deklaracja Praw Seksualnych, która ogłoszona została podczas XIV Światowego Kongresu Seksuologów w Hongkongu, 26 sierpnia 1999 roku a następnie przyjęta i rekomendowana przez Światową Organizację Zdrowia w roku 2002 (Powszechna Deklaracja Praw Seksualnych).

${ }^{31}$ Funkcje prawa omówiono w oparciu o opracowanie Redelbacha (1998), przy czym należy zaznaczyć, że cytowany autor odnosi się do funkcji prawa w znaczeniu ogólnym, nie w odniesieniu do konkretnych ustaw.
} 
względu na intencjonalny brak bezpośredniej sankcji w strukturze normy prawnej. Stąd funkcja represyjna prawa reprezentowana jest jedynie w wybranych zapisach. Wiele norm to normy niesankcjonowalne, tj. pozbawione sankcji - leges imperfectae ${ }^{32}$.

\section{Konfrontacja ustaw}

\section{Systematyka prawa o zwiazkach partnerskich}

Jak wspomniano wyżej, ustawodawcy wyraźnie zaznaczają, że przedmiotem uregulowań są związki partnerskie, a nie małżeństwa homoseksualne. W tekstach nie pojawia się termin Ehe 'małżeństwo', Familie 'rodzina' lecz Partnerschaft 'partnerstwo, wspólnictwo',33. $\mathrm{Z}$ tego też względu nieco odmienna jest systematyka prawa o związkach partnerskich od prawa rodzinnego ${ }^{34}$. Omawiane ustawy sa tekstami o różnej objętości: ustawa niemiecka obejmuje 8 stron formatu $\mathrm{A} 4^{35}$, szwajcarska 24 strony $^{36}$, austriacka zaś $63^{37}$. Ich formalna struktura zewnętrzna - choć niejednolita - wynika w pierwszym rzędzie z gatunku mowy (Textsorte), który reprezentują oraz z funkcji tekstu ${ }^{38}$. Część nieartykułowana analizowanych ustaw obejmuje ${ }^{39}$ :

(i) określenie rodzaju aktu prawnego (nazwę rodzajowa), tu: Gesetz/-gesetz,

(ii) datę uchwalenia,

(iii) nazwę i tytuł aktu (oraz jego skrót ${ }^{40}$ ), tu: fraza przyimkowa $\mathrm{PP}=$ über+N (część nominalna).

\footnotetext{
${ }^{32}$ Analiza dokonana w oparciu o charakterystykę funkcji prawa w pracy Redelbacha $(1998,141)$.

33 Jednokrotnie w ustawie niemieckiej pojawia się jednak zapis, który zmniejsza dystans pomiędzy 'związkiem' a 'rodziną': „Ein Lebenspartner gilt als Familienangehöriger des anderen Lebenspartners, soweit nicht etwas anderes bestimmt ist" (§ 11).

${ }^{34}$ Dla porównania systematyka niemieckiego prawa rodzinnego (Familienrecht): Erster Abschnitt. Bürgerlicher Ehe $§ \$ 1297-1588$. Zweiter Abschnitt. Verwandschaft $\S \S 1589-1772$. Dritter Abschnitt. Vormundschaft. Rechtliche Betreuung. Pflegschaft $\S$ 1773-1921.

${ }^{35}$ Liczba i zawartość podstawowych jednostek redakcyjnych tekstów w dalszej części artykułu.

${ }^{36}$ Sam tekst zasadniczy mieści się na 9 stronach, pozostałe zawierają dział Postanowienia końcowe obejmujący przepisy o wejściu w życie nowego aktu prawodawczego.

${ }^{37} \mathrm{Z}$ czego na treść zasadniczą przypada 11 stron. Pozostała część obejmuje przepisy intertemporalne regulujące oddziaływanie stanowiącego prawa na stosunki powstałe pod działaniem dawnego prawa, w tym wykaz innych aktów prawnych, w których należy odnotować poprawki.

${ }^{38}$ Według typologii tekstów prawnych D. Busse ustawa należy do tekstów o funkcji normatywnej (Textsorten mit normativer Kraft), por. Busse (2000, 669).

${ }^{39}$ Czwartym elementem części nieartykułowanej może być Preambuła, czyli wstęp, który przedstawia ratio legis, tj. motywy wydania aktu normatywnego, cele, podstawowe wartości, jakie utrwala i chroni wydanym aktem. Ta jednak zarezerwowana jest z reguły dla tekstu ustawy zasadniczej. Dla niektórych aktów wymagana jest również podstawa prawna oraz podpis (Korycki et al. 2008, 31-32).

${ }^{40} \mathrm{~W}$ niemieckiej tradycji legislacyjnej skrót aktów prawnych jest obligatoryjnym elementem. W polskim nazewnictwie aktów prawnych procedura ta jest niemal nieobecna.
} 
Tab. 1. Zestawienie części nieartykułowanych

\begin{tabular}{|c|c|c|}
\hline Niemcy & Austria & Szwajcaria \\
\hline $\begin{array}{l}\text { Gesetz über die } \\
\text { Eingetragene } \\
\text { Lebenspartnerschaft } \\
\text { (Lebenspartnerschaftsgesetz } \\
\text { - LPartG) vom 16.2.2001. } \\
\text { (obowiązuje od 1.08. 2001) }\end{array}$ & $\begin{array}{l}\text { Bundesgesetz über die } \\
\text { eingetragene Partnerschaft } \\
\text { (Eingetragene Partnerschaft- } \\
\text { Gesetz - EPG). } \\
\text { (obowiązuje od 1.01.2010) }\end{array}$ & $\begin{array}{l}\text { Bundesgesetz über die } \\
\text { eingetragene Partnerschaft } \\
\text { gleichgeschlechtlicher Paare } \\
\text { (Partnerschaftsgesetz, PartG) } \\
\text { vom 18. Juni 2004. } \\
\text { (obowiązuje od 1.01 2007) }\end{array}$ \\
\hline
\end{tabular}

Różnice w szczegółach w zakresie organizacji i segmentacji tekstu czyli układu elementów technicznych w części artykułowanej, tzn. podział na jednostki wyższego rzędu (Abschnitt / Kapitel), sposób numerowania, jak i zakres przedmiotowy ustaw (zawartość merytoryczna) ilustruje poniższe zestawienie.

Tab. 2. Systematyka ustaw

\begin{tabular}{|c|c|c|}
\hline Niemcy & Austria & Szwajcaria \\
\hline $\begin{array}{l}\text { 1. Abschnitt } \\
\text { Begründung der } \\
\text { Lebenspartnerschaft } \\
\text { 'Zawarcie RZP }\end{array}$ & $\begin{array}{l}\text { 1. Abschnitt } \\
\text { Allgemeine Bestimmungen } \\
\text { 'Postanowienia ogólne' }\end{array}$ & $\begin{array}{l}\text { 1. Kapitel: Allgemeine } \\
\text { Bestimmungen } \\
\text { 'Postanowienia ogólne' }\end{array}$ \\
\hline $\begin{array}{l}\text { 2. Abschnitt } \\
\text { Wirkungen der } \\
\text { Lebenspartnerschaft } \\
\text { 'Skutki prawne RZP' }\end{array}$ & $\begin{array}{l}\text { 2. Abschnitt } \\
\text { Begründung der eingetragenen } \\
\text { Partnerschaft } \\
\text { 'Zawarcie RZP' }\end{array}$ & $\begin{array}{l}\text { 2. Kapitel: Die Eintragung } \\
\text { der Partnerschaft } \\
\text { 'Rejestracja związku' }\end{array}$ \\
\hline $\begin{array}{l}\text { 3. Abschnitt } \\
\text { Getrenntleben der Lebenspartner } \\
\text {,Separacja partnerów' }\end{array}$ & $\begin{array}{l}\text { 3. Abschnitt } \\
\text { Wirkungen der eingetragenen } \\
\text { Partnerschaft } \\
\text { 'Skutki prawne RZP' } \\
\end{array}$ & $\begin{array}{l}\text { 3. Kapitel: Wirkungen der } \\
\text { eingetragenen Partnerschaft } \\
\text { 'Skutki prawne RZP' }\end{array}$ \\
\hline $\begin{array}{l}\text { 4. Abschnitt } \\
\text { Aufhebung der } \\
\text { Lebenspartnerschaft } \\
\text { 'Rozwiązanie RZP' } \\
\end{array}$ & $\begin{array}{l}\text { 4. Abschnitt } \\
\text { Auflösung der eingetragenen } \\
\text { Partnerschaft } \\
\text { 'Rozwiązanie RZP' } \\
\end{array}$ & $\begin{array}{l}\text { 4. Kapitel: Gerichtliche } \\
\text { Auflösung der eingetragenen } \\
\text { Partnerschaft } \\
\text { 'Sądowe rozwiązanie RZP' }\end{array}$ \\
\hline $\begin{array}{l}\text { 5. Abschnitt } \\
\text { Übergangsvorschriften } \\
\text { 'Przepisy przejściowe' }\end{array}$ & $\begin{array}{l}\text { 5. Abschnitt } \\
\text { Nichtigkeit der eingetragenen } \\
\text { Partnerschaft } \\
\text { 'Unieważnienie RZP' }\end{array}$ & $\begin{array}{l}\text { 5. Kapitel: } \\
\text { Schlussbestimmungen } \\
\text { 'Postanowienia końcowe' }\end{array}$ \\
\hline $\begin{array}{l}\text { 6. Abschnitt } \\
\text { Länderöffnungsklausel } \\
\text { 'Klauzula krajów związkowych' }\end{array}$ & $\begin{array}{l}\text { 6. Abschnitt } \\
\text { Folgen der Auflösung oder der } \\
\text { Nichtigkeit } \\
\text { 'Skutki rozwiązania lub } \\
\text { unieważnienia' }\end{array}$ & \\
\hline & $\begin{array}{l}\text { 7. Abschnitt } \\
\text { Sinngemäß anwendbares Bundesrecht } \\
\text { 'Zastosowanie prawa federalnego w } \\
\text { kontekście RZP' }\end{array}$ & \\
\hline & $\begin{array}{l}\text { 8. Abschnitt } \\
\text { Übergangs- und } \\
\text { Schlussbestimmungen } \\
\text { 'Przepisy przejściowe i } \\
\text { postanowienia końcowe' }\end{array}$ & \\
\hline
\end{tabular}

${ }^{41} \mathrm{RZP}=$ rejestrowany związek partnerski. Wszystkie tłumaczenia pochodzą od autora artykułu. 


\section{Szczegóty strukturalne}

Jeśli chodzi o technikę legislacyjną, warto wskazać na brak jednolitości w strukturze dokumentów. Różnice w części artykułowanej, zawierającej zasadniczą materię aktu normatywnego, podyktowane są najprawdopodobniej tradycją i najwyraźniej dostrzegalne są przy porównaniu właściwych jednostek redakcyjnych ustawy, tj. w ilości i układzie drobniejszych segmentów tekstu. Zauważalne jest ponadto podobieństwo pomiędzy niemieckim i austriackim sposobem redagowania tekstu.

Tab. 3. Struktura ustaw w części artykułowanej

\begin{tabular}{|l|l|l|}
\hline Niemcy & Austria & Szwajcaria \\
\hline Abschnitt 1 & 1. Abschnitt & 1. Kapitel: Tytuł działu \\
Tytuł działu Błąd! & Tytuł działu & 1. Abschnitt: Tytuł sekcji \\
Nieprawidłowy & Tytuł paragrafu & Art. 1 Tytuł artykułu \\
odsyłacz typu & § 1. tekst & 1 tekst \\
hiperłącze. & Tytuł paragrafu & 2 tekst \\
§ 1 Tytuł paragrafu & §2. (1) tekst & 3 tekst \\
(1) tekst & 1. tekst & Art. 2 Tytuł artykułu \\
(2) tekst & 2. tekst & 1 tekst \\
1. tekst & $(2)$ tekst & 2 tekst \\
2. tekst & $(3)$ tekst & 3 tekst \\
3. tekst & §3. Tytuł paragrafu & 2. Abschnitt: Tytuł sekcji \\
(3) tekst & $(1)$ tekst & Art. 3 Tytuł artykułu \\
$\ldots$ & 1. tekst & 1 tekst \\
$\S 2$ Tytuł paragrafu & 2. tekst & 2 tekst \\
(1) tekst & $(2)$ tekst & 3 tekst \\
1. tekst & $(3)$ tekst & $\ldots$ \\
2. tekst & $\ldots$ & \\
(2) tekst & & \\
$\ldots$ & & \\
\hline
\end{tabular}

Wszystkie jednak stanowią sformalizowany system nawigacji tekstu i zapewniają szybką orientację w treści dokumentu. Sytuacji tej sprzyjają niewielkie rozmiary poszczególnych działów, sekcji i paragrafów (artykułów). Ten fakt wynika natomiast z licznych odsyłaczy i odwoływania się do obowiązujących przepisów kodeksu cywilnego, które uzupełniają treść ustaw.

\section{Ustalenia szczegótowe (na przykładzie wybranych zagadnień) $)^{42}$}

(i) Zawarcie związku.

Wszystkie ustawy zgodnie formułują podstawowe wymagania wobec osób pragnących zawrzeć związki partnerskie. Warunkiem rejestracji związku jest pełnoletniość partnerów

\footnotetext{
${ }^{42}$ Ze względy na rozmiary artykułu przedstawienie szczegółowej i wyczerpującej analizy porównawczej trzech ustaw jest niemożliwe. Ograniczam się do wybranych rozwiązań legislacyjnych o stosunkowo szerokim zakresie działania oraz do wskazania, jak dane zagadnienie zostało sformułowane w innej ustawie.
} 
tej samej płci i pełna zdolność do czynności prawnych ${ }^{43}$. Związku nie mogą zarejestrować osoby różnej płci, będące rodzeństwem, rodzeństwem przyrodnim, krewnymi w linii prostej oraz pozostające w innym związku partnerskim lub małżeńskim. Rejestracja odbywa się osobiście przed urzędnikiem stanu cywilnego (bez konieczności obecności świadków ${ }^{44}$ ) poprzez złożenie zgodnego pisemnego oświadczenia o wstąpieniu w związek partnerski ${ }^{45}$. Tylko ustawa niemiecka stanowi, że po zawarciu związku partner staje się członkiem rodziny (Familienangehöriger) i wchodzi w relacje powinowactwa (Schwägerschaft) z krewnymi partnera. Powinowactwo nie ustaje po rozwiązaniu związku.

(ii) Nazwisko partnerów.

Z woli prawodawcy austriackiego partnerzy zachowują swoje dotychczasowe nazwiska $(\text { Abs. } 3 \$ 7)^{46}$. Inaczej stanowi prawo niemieckie, zgodnie z którym partnerzy mogą ustalić wspólne nazwisko po zawarciu związku partnerskiego (Lebenspartnerschaftsname), którym może być metrykalne nazwisko jednego z partnerów, przy czym dotychczasowe nazwisko może figurować jako pierwszy człon nowego nazwiska złożonego (Doppelnamen). Nazwisko przyjęte po rejestracji związku obowiązuje również po jego ustaniu (Abs.2 §3). Ustawa szwajcarska nie podejmuje wątku zmiany nazwiska.

(iii) Utrzymanie związku.

Niemiecka, szwajcarska i austriacka ustawa zgodnie - w jednym z pierwszych paragrafów w części poświeconej skutkom rejestracji związku partnerskiego - nakładają na partnerów obowiązek wspólnego mieszkania, dbania o związek, udzielania sobie wzajemnej pomocy i wsparcia, pożycia w duchu wzajemnego zaufania, poszanowania i harmonijnego zaspokajania potrzeb. Partnerzy wspólnie działają, wspólnie planują przyszłość, wspólnie dbają o interesy związku, prowadzą wspólne gospodarstwo domowe oraz są zobowiązani do utrzymywania związku. Ignorowanie tego obowiązku skutkuje przymusem sądowym (Szwajcaria). Łożenie na związek powinno uwzględniać własne dochody i nie wygasa $\mathrm{z}$ momentem zaprzestania prowadzenia wspólnego gospodarstwa domowego (Austria). Partnerzy mają równe prawa (Austria), pozostają we wspólnocie majątkowej, chyba że zawarta wcześniej odrębna umowa stanowi inaczej (Niemcy).

(iv) Opieka nad dziećmi (partnera).

To zagadnienie reguluje $\S 9$ pierwszego rozdziału w ustawie niemieckiej. Zapis uprawnia partnera do reprezentowania dziecka w bieżących sprawach życia codziennego, pod warunkiem, że pozostaje ono pod wyłączną władzą rodzicielską drugiego partnera ${ }^{47}$, a ten czasowo nie może sprawować nad nim opieki. W przypadku zagrożenia życia lub zdrowia dziecka partner jest uprawniony do podejmowania działań prawnych mających na celu jego dobro. Dziecko wychowywane w związku partnerskim (pod wyłączną władzą rodzicielską jednego z partnerów) może przyjąć nazwisko związku. W sposób ogólny i powściągliwy wypowiada się ustawodawca szwajcarski: partner wspiera

\footnotetext{
${ }^{43}$ Osoby niepełnoletnie wymagają zgody opiekunów prawnych.

${ }^{44}$ Ustawa niemiecka dopuszcza możliwość (nie jest to wymogiem) uczestniczenia do dwóch świadków, por. Abs. $1 \S 1(2)$.

45 Istotnym elementem odróżniającym zawarcie związku małżeńskiego i zawarcia związku partnerskiego jest brak przysięgi i brak wymogu obecności świadków.

${ }^{46}$ Dosł.: Die eingetragenen Partner behalten ihren bisherigen Namen bei.

${ }^{47}$ Przywilej ten może być jednak ograniczony lub odebrany przez sąd rodzinny, o ile służy to dobru dziecka (Abs.1 $\$ 9(3))$.
} 
i pomaga w wychowaniu dziecka bez nabycia prawa rodzicielskiego (Art. 27). Ustawa austriacka zupełnie nie podejmuje tego wątku.

(v) Adopcja dzieci.

Wszystkie przedmiotowe ustawy wykluczają możliwość adopcji dzieci i starania się o potomstwo przez partnerów pozostających w związku partnerskim.

(vi) Prawo spadkowe.

Niemiecka ustawa stanowi, że partnerowi przysługuje prawo dziedziczenia. W zależności od ilości osób dziedziczących i ich stopnia pokrewieństwa przysługuje mu jedna czwarta wartości spadku (wraz z krewnymi pierwszego stopnia) lub połowa spadku (wraz z krewnymi drugiego stopnia). Ponadto - dodatkowo - przysługuje mu prawo do dziedziczenia wyposażenia wspólnie prowadzonego gospodarstwa domowego (tzw. der Voraus $^{48}$ ), o ile nie jest on elementem przynależnym nieruchomości (jak np. piec w piekarni, traktor w gospodarstwie rolnym itp.). W przypadku braku innych spadkobierców partner dziedziczy cały spadek. Sprawy dziedziczenia mogą być uregulowane w testamencie. Prawo dziedziczenia nie przysługuje, jeśli testator przed śmiercią złożył pozew o rozwiązanie związu. Identyczny zapis zawiera ustawa szwajcarska (Art.31). W Austrii i Szwajcarii partnerzy dziedziczą po sobie jak małżonkowie.

(vii) Rozwiązanie związku ${ }^{49}$.

Rozwiązanie związku następuje we wszystkich krajach na mocy wyroku sądowego. W Niemczech dzieje się to z inicjatywy jednego lub obu partnerów, gdy:

- $\quad$ partnerzy od roku nie mieszkają razem i obydwoje składają pozew o rozwiązanie związku lub jeśli nie ma przesłanek do kontynuowania udanego związku,

- $\quad$ jeden z partnerów składa wniosek, jeśli partnerzy nie mieszkają ze sobą przez trzy lata,

- $\quad$ porozumienie między partnerami stało się niemożliwe, a wynika to z zachowania drugiego partnera.

Rozwiązanie związku następuje w przypadku, gdy partnerzy nie mieszkają razem, nie prowadzą wspólnego gospodarstwa domowego (häusliche Gemeinschaft) i nie wyrażają woli na jego przywrócenie. W ustawie szwajcarskiej rozwiązanie związku następuje sądownie po nieprzymuszonym wyrażeniu woli obojga partnerów lub na wniosek jednej ze stron, o ile partnerzy nie mieszkają razem co najmniej przez rok. Zdecydowanie więcej miejsca poświęcono temu zagadnieniu w austriackiej ustawie (w całości 4. Abschnitt, §13-18). Związek ulega automatycznie rozwiązaniu na skutek śmierci jednego $\mathrm{z}$ partnerów lub $\mathrm{w}$ wyniku postępowania sądowego. Ten drugi sposób może być pochodną różnych sytuacji. Pozew o rozwiązanie związu można złożyć w wyniku braku wiedzy lub braku oświadczenia woli jednej ze stron. W szczególności, jeśli:

- $\quad$ w momencie rejestracji związku partner nie miał zdolności do czynności prawnych lub gdy prawny opiekun partnera nie wyraził zgody na zawarcie związku,

\footnotetext{
${ }^{48}$ Szczegółowe uregulowania zawiera $\$ 1932$ BGB.

${ }^{49}$ Uregulowania dotyczące unieważnienia związku ujęte zostały dodatkowo w tekście ustawy austriackiej (5. Abschnitt, §19) i szwajcarskiej (3. Abschnitt: Art.9-11).
} 
- osoba wchodząca w związek pomyliła w wyborze partnera (wybrała nieodpowiedniego partnera $^{50}$ ),

- $\quad$ zawarcie związu nastąiło pod wpływem groźby,

- $\quad$ osoba była nieświadoma, że zawiera związek partnerski.

Druga grupa czynników opatrzona została wspólnym nagłówkiem: Z winy partnera i wskutek rozkładu związku ${ }^{51}$. Dotyczy to czynów i wykroczeń, których dopuścił się jeden z partnerów, w wyniku których kontynuowanie związku jest niemożliwe: w szczególności chodzi o dopuszczenie się przemocy fizycznej lub psychicznej $(\S 15)^{52}$. Pozew o rozwiązanie związku może złożyć jedna ze stron, jeśli:

- jeden $\mathrm{z}$ partnerów ma zaburzenia psychiczne lub jest psychicznie chory, w wyniku czego nie ma przesłanek do poprawnego funkcjonowania związku,

- $\quad$ partner cierpi na chorobę zakaźną lub inną chorobę budząca odrazę, której okres leczenia lub zażegnania niebezpieczeństwa zarażenia się jest niemożliwy do ustalenia $^{53}$,

- $\quad$ jeśli partnerzy nie pozostają we wspólnym gospodarstwie domowym przez okres trzech lat.

Wspólny wniosek w formie pisemnego oświadczenia mogą złożyć obie strony, o ile ustało pożycie w związku i stan ten trwa przynajmniej pół roku. Rozwiązanie związku może zakończyć się wyrokiem sądu z oświadczeniem o winie. Fakt ten ma swoje konsekwencje w uregulowaniach finansowych po ustaniu związku (patrz punkt viii: zobowiązania po ustaniu związku).

(viii) Zobowiązania po ustaniu związku.

Niemiecka i szwajcarska ustawa zakłada, że po ustaniu związku każdy z partnerów jest zobligowany do samodzielnego utrzymywania się. W Szwajcarii partner, który $\mathrm{w}$ wyniku podziału ról $\mathrm{w}$ związku ograniczył pracę zarobkową lub zrezygnował z niej, może wymagać od swojego partnera środków na utrzymanie, stosownie do możliwości zarobkowych i majątkowych zobowiązanego, aż do momentu podjęcia pracy zarobkowej. Podobnie jeżeli w wyniku rozwiązania rejestrowanego związku partnerskiego sytuacja życiowa jednego z partnerów uległa istotnemu pogorszeniu, może on domagać się od byłego partnera dostarczania środków na utrzymanie ${ }^{54}$. W Niemczech w przypadku braku możliwości podjęcia pracy zarobkowej partner ma prawo do ubiegania się o alimenty od byłego uczestnika związku zgodnie z $\$ \S 1570$ do $1586 \mathrm{~b}$ oraz $1609 \mathrm{BGB}^{55}$. Losy nieruchomości (mieszkania) oraz ruchomości (wyposażenie wspólnego gospodarstwa domowego) po ustaniu związku regulują §§ 1568a oraz 1568b BGB. Ustawa niemiecka zawiera wzorcem kodeksu rodzinnego wzmiankę (§20)

\footnotetext{
${ }^{50}$ Dosł. ,[...] sich in der Person des anderen irrte”, por. §14 (1).

${ }^{51}$ Dosł. „Auflösung wegen Verschuldens oder wegen Zerrüttung““.

${ }^{52}$ Zapis ten nie ma mocy prawnej, o ile osoba poszkodowana wybaczy zachowanie partnera lub nie uzna go za szczególnie zagrażające związkowi (§16 (1)) oraz jeśli skarga nie zostanie wniesiona w ciągu sześciu miesięcy $(\$ 16(2))$.

${ }^{53}$ Zapis nie ma zastosowania, jeśli jest naganny z moralnego punktu widzenia: jeśli rozwiązanie związku byłoby poważnym ciosem dla partnera. $\mathrm{W}$ analizie przypadków jednostkowych bierze się pod uwagę wiek partnera, czas trwania związku oraz okoliczności zachorowania.

${ }_{54}$ Pozostałe przypadki reguluje art. 125 ust. 3 oraz art.126-132 ZGB (Zivilgesetzbuch=kodeks cywilny) o utrzymaniu po ustaniu małżeństwa (der nacheheliche Unterhalt).

${ }^{55}$ Bürgerliches Gesetzbuch (kodeks cywilny).
} 
o wyrównaniu roszczeń istniejących w stosunkach między rozwodnikami dot. różnicy $\mathrm{w}$ wysokości nabytych $\mathrm{w}$ trakcie trwania związku praw do zaopatrzenia emerytalnorentowego (Versorgungsausgleich) ${ }^{56}$.W Szwajcarii po ustaniu związku strony traca ustawowe prawo do dziedziczenia.

Dosyć obszernie i bardziej szczegółowo reguluje relacje między partnerami po ustaniu związku ustawa austriacka (6. Abschnitt \$20-42). Strona z orzeczeniem o winie jest zobowiązana zapewnić utrzymanie swojemu byłemu partnerowi, o ile jego dochody z pracy zarobkowej lub innych źródeł są niewystarczające. W przypadku winy obustronnej prawo do roszczenia dostarczania środków niezbędnych do zaspokajania usprawiedliwionych potrzeb (świadczenia alimentacyjne) ma partner, który (czasowo) nie może sam sobie zapewnić bytu. Obowiązek ten może być ograniczony w czasie. O ile jedna ze stron $\mathrm{w}$ trakcie trwania związku $\mathrm{z}$ różnych przyczyn nie podejmowała pracy zarobkowej, ewentualnie zaniechała zdobycia wykształcenia i z tego powodu lub ze względu na wiek, stan zdrowia nie może zapewnić sobie bytu, zobowiązuje się byłego partnera do świadczenia alimentacyjnego. Ustalony sądownie wyrok dotyczący świadczeń jest ograniczony w czasie (do trzech lat) lub do momentu podjęcia pracy zarobkowej. Prawo do alimentów ma ograniczone działanie lub nie przysługuje osobom, które dopuściły się szczególnych wykroczeń, są obciążone winą o rozpadzie związku lub jeśli związek trwał zbyt krótko.

Ustaniu związku towarzyszy zwykle podział majątku (ruchomości, nieruchomości, oszczędności), który został zgromadzony i używany w trakcie trwania związku. W podziale nie mogą być uwzględnione:

- $\quad$ przedmioty majątkowe, które jedna ze stron wniosła do związku (np. mieszkanie) bądź weszła $\mathrm{w}$ ich posiadanie $\mathrm{z}$ tytułu dziedziczenia, zapisu lub darowizny od osoby trzeciej,

- $\quad$ przedmioty osobistego użytku oraz przedmioty służące do wykonywania zawodu.

W przypadku braku porozumienia odnośnie do podziału każdy z partnerów może żądać przeprowadzenia podziału majątku przez sąd.

Prawodawca niemiecki podjął ponadto próbę uregulowania stosunków między partnerami w przypadku separacji (Abschnitt 3). Stan ten może stać się podstawą roszczeń świadczeń alimentacyjnych. Ponadto podziałowi podlegają wszystkie wspólne ruchomości (np. sprzęty gospodarstwa domowego). Sąd może wyznaczyć finansowe odszkodowanie za używanie niektórych sprzętów. Zmianom nie ulega prawo własności. W przypadku wyprowadzenia się ze wspólnego mieszkania i braku informacji o zamiarze powrotu w ciągu sześciu miesięcy, zachodzi domniemanie, że uczestnik związku scedował prawo użytkowania mieszkania na wyłączność swojego partnera, który pozostał w mieszkaniu.

\section{Rozwiązania terminologiczne}

\footnotetext{
${ }^{56}$ Postępowanie prowadzone $\mathrm{w}$ Niemczech $\mathrm{w}$ ramach procesu rozwodowego. Szczegółowe uregulowania zawierają $\$ 1587$ i $1587 \mathrm{a}-1587 \mathrm{p}$ BGB
} 
$\mathrm{Na}$ płaszczyźnie językowej można stwierdzić przede wszystkim zróżnicowaną terminologię (pod względem formy) nie tylko między ustawami, ale również wewnątrz jednego dokumentu. I tak np. w dokumencie niemieckim stwierdzić można szereg określeń synonimicznych $\mathrm{w}$ odniesieniu do przedmiotowych pojęć, tj. 'związku partnerskiego' jak i 'partnerów'. Zebrany materiał uchodzić może za leksykalną specyfikę omawianych aktów prawnych. Warto zauważyć nierówny udział terminologii w badanych ustawach. Najwyższe nasycenie charakterystyczną leksyką, tj. udział terminów specjalistycznych wykazuje najstarsza ustawa (patrz Tab. 4.), co czyni tekst bardziej wyrazistym.

Dyferencjacja w terminologii uchwytna jest w samej nazwie ustaw i ich skrótach. Niemieckiemu Lebenspartnerschaft odpowiada Partnerschaft w pozostałych tytułach ustaw; przydawka dopełniaczowa gleichgeschlechtlicher Paare jest elementem składowym tylko w tytule ustawy szwajcarskiej (por. Tab. 1). Z komentarza do ustawy szwajcarskiej wynika jednak, że niemiecki dokument był uwzględniany przy opracowywaniu ustawy. Szwajcarscy autorzy tekstu ustawy świadomie odrzucili niemieckie określenie eingetragene Lebenspartnerschaft, przejmując jedynie eingetragene Partnerschaft, co uzasadnili następującym argumentem: „Auch im Interesse einer internationalen Begriffsharmonisierung trägt das neue schweizerische Rechtsinstitut nun den Namen «eingetragene Partnerschaft». Die Verkürzung stellt sicher, dass im französischen und italienischen Gesetzestext nicht schwerfällige Umschreibungen verwendet werden müssen“ (Botschaft 2002, 90). Jeśli jednak uwzględnimy semantykę omawianych określeń oraz wymogi stawiane terminom specjalistycznym (Pieńkos 1993, 210), termin niemiecki jest z pewnością odpowiedniejszy, ponieważ jego zakres odniesienia jest węższy, tzn. precyzuje on, o jaki charakter związku partnerskiego chodzi: Leben+s+partnerschaft (=niem. Leben - życie, Partnerschaft - partnerstwo), przez co jest jednoznaczny. Sam leksem Partnerschaft jest polisemiczny, stąd być może - zdaniem autorów ustawy z Niemiec - mniej predysponowany do pełnienia funkcji terminu specjalistycznego. Względy praktyczne podniesione $\mathrm{w}$ argumentacji ustawodawcy szwajcarskiego przemawiają jednak za formą uproszczoną wykorzystaną w szwajcarskim i austriackim tekście ustawy. Należy pamiętać, że kontekst użycia danej jednostki leksykalnej precyzuje jej wartość semantyczną. Ustalenie aktualnego znaczenia wyrazu bądź grupy wyrazów polega m.in. na rozpatrzeniu kontekstu ich użycia (Zawadowski 1951,9). Analogiczne zasady dotyczą terminów w wypowiedziach prawnych (Pieńkos 1999, 53). Termin z niemieckiej ustawy potraktować należy jako wariant regionalny.

Charakterystyczne w tekście niemieckim i szwajcarskim jest konsekwentne używanie form męskich i ich żeńskich derywatów (movierte Nomina) w odniesieniu do partnerów (Partner, Partnerin), podczas gdy tekst austriacki zawiera jedynie forme męską (Partner) ${ }^{57}$. Językowe ujęcie adresatów tekstów oficjalnych i urzędowych, jakie odnajdujemy w austriackim dokumencie, jest sprzeczne z normą językową obowiązującą

\footnotetext{
57 Fakt ten może nieco dziwić, ponieważ tekst konstytucji Republiki Austrii podejmuje wątek równouprawnienia płci w języku: „Amtsbezeichnungen können in der Form verwendet werden, die das Geschlecht des Amtsinhabers oder der Amtsinhaberin zum Ausdruck bringt. Gleiches gilt für Titel, akademische Grade und Berufsbezeichnungen“(Art.7 (3)).
} 
w Niemczech ${ }^{58}$, godzi również w zasadę równouprawnienia płci i politycznej poprawności. Stanowi jednak lokalny koloryt tekstu. W wyniku ekscerpcji określeń odnoszacych się do związków partnerskich, ich funkcjonowania oraz uczestników związków uzyskałem repertuar środków językowych, które w niemieckojęzycznych tekstach prawnych i prawniczych uchodzą za terminy specjalistyczne ${ }^{59}$. Zgodnie zresztą z definicją, jaką przytacza R. Kocourek, według której „termin jest jednostką leksykalną określoną w specjalistycznym tekście" (Kocourek 1982,77, cyt. za Pieńkos 1993, 209).

Tab. 4. Zestawienie terminologiczne

\begin{tabular}{|c|c|c|}
\hline Niemcy & Austria & Szwajcaria \\
\hline \multicolumn{3}{|c|}{ a. określenia dotyczące związku ${ }^{60}$} \\
\hline $\begin{array}{l}\text { - eine Partnerschaft auf } \\
\text { Lebenszeit } \\
\text { - Lebenspartnerschaft } \\
\text { - lebenspartnerschaftliches } \\
\text { Verhältnis } \\
\text { - die partnerschaftliche } \\
\text { Lebensgemeinschaft } \\
\text { - die lebenspartnerschaftliche } \\
\text { Gemeinschaft } \\
\text { - Begründung/ Beendigung der } \\
\text { Lebenspartnerschaft } \\
\text { - eine Partnerschaft gründen, } \\
\text { aufheben } \\
\text { - eine Lebenspartnerschaft } \\
\text { begründen } \\
\text { - eine Partnerschaft auf } \\
\text { Lebenszeit führen } \\
\text { - die partnerschaftliche } \\
\text { Lebensgemeinschaft } \\
\text { unterhalten } \\
\text { - Aufhebung der } \\
\text { Lebenspartnerschaft } \\
\text { - die Aufrechterhaltung der } \\
\text { Lebenspartnerschaft }\end{array}$ & $\begin{array}{l}\text { - eingetragene } \\
\text { Partnerschaft } \\
\text { - gleichgeschlechtliche } \\
\text { Paare } \\
\text { - Lebensgemeinschaft } \\
\text { - die partnerschaftliche } \\
\text { Lebensgemeinschaft } \\
\text { - partnerschaftliches } \\
\text { Verhältnis } \\
\text { - Lebensgemeinschaft auf } \\
\text { Dauer } \\
\text { - eingetragene } \\
\text { Partnerschaft begründen } \\
\text { - Begründung der } \\
\text { eingetragenen Partnerschaft } \\
\text { - Aufhebung des } \\
\text { gemeinsamen Haushalts } \\
\text { - Auflösung der } \\
\text { eingetragenen Partnerschaft } \\
\text { - häusliche Gemeinschaft } \\
\text { aufheben } \\
\text { - die Lebensgemeinschaft } \\
\text { aufheben } \\
\text { - die Gemeinschaft } \\
\text { herstellen } \\
\text { - die eingetragene }\end{array}$ & $\begin{array}{l}\text { - eingetragene Partnerschaft } \\
\text { - gleichgeschlechtliche Paare } \\
\text { - Lebensgemeinschaft } \\
\text { - Gemeinschaft } \\
\text { - Zusammenleben } \\
\text { - Eintragung der Partnerschaft } \\
\text { - eingetragene Partnerschaft } \\
\text { eingehen } \\
\text { - in eingetragener } \\
\text { Partnerschaft leben } \\
\text { - Lebensgemeinschaft } \\
\text { begründen } \\
\text { - Aufhebung des } \\
\text { Zusammenlebens } \\
\text { - Zusammenleben ablehnen } \\
\text { - die eingetragene Partnerschaft } \\
\text { Auflösen } \\
\text { - Auflösung der eingetragenen } \\
\text { Partnerschaft }\end{array}$ \\
\hline
\end{tabular}

58 Uregulowania dotyczące używania form neutralnych w niemieckiej korespondencji urzędowej oraz w oficjalnych aktach normatywnych mają charakter obligatoryjny. Wskazówki i zalecenia zawiera tekst Gleichstellung von Frau und Mann in der Rechts- und Amtssprache Gem. RdErl. d. Justizministeriums (1030 II A. 325), d. Ministerpräsidenten und aller Landesministerien vom 24. März 1993.

${ }^{59}$ Pieńkos wprowadza obok określenia ‘termin' dodatkowo rozróżnienie 'quasi-terminy' i ‘specjalne jednostki leksykalne' (Pieńkos 1993, 209).

${ }^{60}$ Dla przejrzystości oddzielono asteryskiem (*) frazy nominalne nazywające związek od derywowanych od nich fraz werbalnych (wzgl. zawierających dewerbatiwa). 


\begin{tabular}{|c|c|c|}
\hline & $\begin{array}{l}\text { Partnerschaft auflösen } \\
\text { - Nichtigkeit der } \\
\text { eingetragenen Partnerschaft } \\
\text { - eingetragene } \\
\text { Partnerschaft } \\
\text { für nichtig erklären }\end{array}$ & \\
\hline \multicolumn{3}{|l|}{ b. określenia dotyczące osób } \\
\hline $\begin{array}{l}\text { - zwei Personen gleichen } \\
\text { Geschlechts } \\
\text { - Lebenspartnerinnen oder } \\
\text { Lebenspartner } \\
\text { - die Lebenspartner }\end{array}$ & $\begin{array}{l}\text { - eingetragene Partner } \\
\text { - beide Partner } \\
\text { - die (beklagte) Partei } \\
\text { - gleichgeschlechtliche } \\
\text { Paare } \\
\text { - beide Teile }\end{array}$ & $\begin{array}{l}\text { - beide Partnerinnen oder } \\
\text { Partner } \\
\text { - eine der Partnerinnen oder } \\
\text { einer der Partner } \\
\text { - Person (,Hat eine Person } \\
\text { Kinder...") } \\
\text { - Personen, die in einer } \\
\text { eingetragenen Partnerschaft } \\
\text { leben } \\
\text { - Personen gleichen Geschlechts }\end{array}$ \\
\hline \multicolumn{3}{|l|}{ c. określenie wspólnego mienia } \\
\hline $\begin{array}{l}\text { - die gemeinsame Wohnung } \\
\text { - die ihm gehörenden } \\
\text { Haushaltsgegenstände } \\
\text { - lebenspartnerschaftlicher } \\
\text { Haushalt } \\
\text { - häusliche Gemeinschaft } \\
\text { - Haushaltsgegenstände, die } \\
\text { den } \\
\text { Lebenspartnern gemeinsam } \\
\text { gehören } \\
\text { - gemeinsamer Haushalt } \\
\text { - gemeinsamer Wohnsitz }\end{array}$ & $\begin{array}{l}\text { - gemeinsamer Haushalt } \\
\text { - Haushaltsgemeinschaft } \\
\text { - häusliche Gemeinschaft } \\
\text { der eingetragenen Partner } \\
\text { - das partnerschaftliche } \\
\text { Gebrauchsvermögen } \\
\text { - die partnerschaftlichen } \\
\text { Ersparnisse } \\
\text { - der Hausrat und die } \\
\text { gemeinsame Wohnung } \\
\text { - die partnerschaftliche } \\
\text { Wohnung }\end{array}$ & $\begin{array}{l}\text { - gemeinsame Wohnung } \\
\text { - gemeinsame Wohnräume }\end{array}$ \\
\hline \multicolumn{3}{|l|}{ d. inne określenia } \\
\hline $\begin{array}{l}\text { - Lebenspartnerschaftsvertrag } \\
\text { - Lebenspartnerschaftsname } \\
\text {-Lebenspartnerschaftsunterhalt } \\
\text { - gemeinsame } \\
\text { Lebensgestaltung } \\
\text { - nachpartnerschaftlicher } \\
\text { Unterhalt } \\
\text { - ein gemeinschaftliches } \\
\text { Testament } \\
\text { - Lebenspartnerschaftszeit } \\
\text { - Lebenspartnerschaftsrecht } \\
\text { - Lebenspartnerschaftsregister } \\
\text { einrichten }\end{array}$ & & \\
\hline
\end{tabular}


Zestawiona powyżej leksyka podkreśla pochodzenie tekstów $\mathrm{z}$ jednego regionu językowego, lecz z różnych kręgów kulturowych o odmiennej kulturze prawnej i wynika najprawdopodobniej z braku ustalonych tradycją terminów, z drugiej zaś z istnienia regionalnych odmianek $w$ systemie leksykalnym i frazeologicznym niemczyzny w Szwajcarii, Austrii i Republiki Federalnej (por. niem. i austr. eine Partnerschaft aufheben vs. szwajc. eine Partnerschaft auflösen).

Analiza tekstów z perspektywy terminologii specjalistycznej wyłoniła dosyć pokaźny asortyment specyficznych dla problematyki określeń oraz ich wariantów bliskoznacznych, odkrywając jednocześnie, szczególnie w tekście ustawy ze Szwajcarii pewną chwiejność, niekiedy wręcz nieporadność stylistyczną (np. użycie określeń beide Partnerinnen oder Partner, Person, Personen, die in einer eingetragenen Partnerschaft leben w kontekstach, w których termin eingetragene( $r$ ) Partner w sposób jednoznaczny i precyzyjny definiowałby denotat). Przyczyn tej ostatniej upatrywać należy w fakcie, że terminologia jeszcze się nie ustabilizowała.

\section{Implikacje przekładoznawcze}

Kluczowym terminem analizowanych tekstów ustaw jest eingetragene Partnerschaft. Najodpowiedniejszym i najbardziej naturalnym jego polskim odpowiednikiem wydaje się być fraza nominalna zwiqzek partnerski. Pewnym argumentem przemawiającym za takim rozwiązaniem jest choćby jego obecność w projekcie ustawy senator Marii Szyszkowskiej z 2004 roku. Można się jednak spodziewać, że termin ten może natrafić na opór ustawodawcy. Określenie zwiazek partnerski jest w pewnym zakresie obciążony semantycznie i denotuje w powszechnym uzusie językowym związek kobiety i mężczyzny (małżeński i pozamałżeński), oparty na pewnych zasadach. Stąd, by uniknąć definiowania pojęć wbrew znaczeniu już funkcjonującemu w świadomości użytkowników języka, można się spodziewać rozwiązań typu: rejestrowany zwiazek partnerski, (rejestrowany) zwiazek osób tej samej ptci, (rejestrowany) zwiqzek między osobami tej samej ptci, zwiqzek osób homoseksualnych.

Mnogości określeń osób w niemieckojęzycznych tekstach ustaw (Tabela 4., pkt. b) odpowiadać będzie raczej jeden termin partner/partnerzy, partnerka/partnerki względnie ich synonimiczna parafraza osoby tej samej ptci. W uzasadnionych przypadkach dopuścić należy nieco bezosobowo brzmiąca frazę uczestnik zwiazku/uczestniczka zwiazku. Ze względów stylistycznych można ponadto sięgnąć po formy opisowe, np. partner pozostajacy w rejestrowanym zwiazku partnerskim, osoba uczestniczqca wzwiazku, uczestnik rejestrowanego zwiazku osób tej samej ptci. Kontekstowo akceptowalny może być termin druga strona, jedna ze stron. Ze względu na relację konwergencji niemieckich i polskich jednostek leksykalnych w tłumaczeniu na język polski musi zatem dojść do redukcji. Obok trudności w znalezieniu oddzielnego odpowiednika prawnego dla niemieckich kompozytów typu Lebenspartner/Lebenspartnerin czy der eingetragene Partner pojawia się pytanie o konieczność tworzenia nowych bytów terminologicznych. Polski leksem partner należy wprawdzie do wokabularza słownictwa potocznego, w proponowanym użyciu sekundarnym w określonym kontekście może pełnić rolę terminu specjalistycznego. 
Pozostałe terminy i jednostki leksykalne wyodrębnione w punkcie 4. nie powinny nastręczać trudności w przekładzie, gdyż są znane z innych aktów prawnych lub - ze względu na swój charakter - mogą być oddane w tłumaczeniu syntagmatycznym bądź za pomoca parafrazy. I tak przydawkom lebenspartnerschaftlich, partnerschaftlich (Tabela 4., pkt. c.) odpowiadać może nienacechowany przymiotnik wspólny względnie jego kontekstowe synonimy $\mathrm{w}$ postaci frazy $\mathrm{z}$ przydawką dopełniaczową oszczędności partnerów (die partnerschaftlichen Ersparnisse) lub formy opisowej oszczędności powstate $w$ trakcie trwania zwiazku itp. Za kluczowe frazy werbalne w polskim tekście (tłumaczeniu) o dyskutowanej tutaj instytucji prawnej uznać należy:

- $\quad$ eine Partnerschaft (be)gründen/ eingetragene Partnerschaft eingehen $\rightarrow$ zawrzeć zwiazek partnerski, wstapić w zwiazek partnerski;

- $\quad$ in eingetragener Partnerschaft leben $\rightarrow$ pozostawać $w$ zwiazku, żyć $w$ zwiazku partnerskim;

- $\quad$ eine Partnerschaft aufheben/auflösen $\rightarrow$ rozwiazać zwiazek;

- eingetragene Partnerschaft für nichtig/ungültig erklären $\rightarrow$ unieważnić, stwierdzić nieważność zwiazku.

\section{Podsumowanie i uwagi końcowe}

Analizowane ustawy o związkach partnerskich są dowodem aktywności ustawodawczej trzech krajów, w których ten wycinek rzeczywistości społecznej znalazł swoje prawne uregulowania. Sam fakt istnienia rozwiązań legislacyjnych świadczy o zaawansowanych zmianach w obyczajowości, przyzwoleniu społecznym oraz sprawności legislacyjnej organów państwowych. Przedmiotowe ustawy stanowią kompilację prawa podmiotowego i przedmiotowego, które nadaje uczestnikom związku partnerskiego pewne przywileje oraz obliguje do przyjęcia na siebie określonych obowiązków. Zawarcie rejestrowanego związku partnerskiego wiąże się z nabyciem szeregu uprawnień, głównie o charakterze ekonomicznym.

Przedstawione w zarysie treści trzech ustaw wykazują pewną spójność w zakresie części rozwiązań prawnych. Rejestrowany związek partnerski przyznaje partycypującym w nim osobom zazwyczaj część praw z tych, które posiadają małżonkowie. Najistotniejszym uprawnieniem rejestrowanego związku partnerskiego jest przyznanie jego uczestnikom prawa do zawarcia umowy majątkowej, zgodnie z którą powstaje wspólność majątkowa oraz prawo dziedziczenia. Kolejne bardzo istotne uprawnienie partnerów dotyczy świadczeń alimentacyjnych. Wymienione uregulowania są, obok zabezpieczenia partnerów od strony materialnej, elementem umacniającym związek emocjonalny partnerów. Omawiane ustawy w sposób eksplicytny dystansują się od instytucji małżeństwa czy rodziny, nie sposób jednak nie zauważyć analogii do prawa rodzinnego. Stamtąd pochodzi gros rozwiązań. Przykładem mogą być następujące zasady wymieniane zwykle przy omawianiu prawa rodzinnego jako elementy jego fundamentalnej struktury małżeństwa (Fundamentalstruktur der Ehe). Są one wspólne dla trzech omawianych tekstów prawnych: (1) zasada równouprawnienia partnerów (die Gleichberechtigung der Ehegatten), (2) zasada monogamii (die Monogamie), (3) zasada trwałości związku (das Prinzip der Eingehung der Ehe auf Lebenszeit), (4) możliwość rozwiązania związku (die Möglichkeit zur Ehescheidung), (5) zasada swobody zawierania związku (das Prinzip des freien Zugangs zur Ehe), por. (Pawlowski 1999, 411).To, co 
różni przedmiotowe teksty prawne, to niektóre rozwiązania w poszczególnych dziedzinach życia oraz stopień ich szczegółowości ${ }^{61}$.

Powyższe konkluzje pozwalają na ustalenie prowizorycznej typologii analizowanych dokumentów, według kryterium zbieżności zapisów z prawem rodzinnym lub innymi słowy: według stopnia egalitaryzacji związków partnerskich i związków małżeńskich $\mathrm{w}$ rozumieniu prawa. Najwyższy stopień zbliżenia wykazuje ustawa niemiecka (obecność świadków, wspólne nazwisko), najmniej cech wspólnych obu instytucji prawnych zawiera dokument austriacki. Ustawa ze Szwajcarii zajmuje miejsce pośrednie (wzmianka o wychowaniu dzieci).

\section{Bibliografia}

Botschaft 2002=Botschaft zum Bundesgesetz über die eingetragene Partnerschaft gleichgeschlechtlicher Paare vom 29. November 2002 (Bundesblatt BBl 2002 1288, S. 1315). http://www.admin.ch/ch/d/ff/2003/1288.pdf (data dostępu 3 września 2010 r.).

Busse, Dietrich. 2000. „Textsorten des Bereichs Rechtswesen und Justiz”. W: Text- und Gesprächslinguistik. Ein internationales Handbuch zeitgenössischer Forschung, red. Gerd Antos, Klaus Brinker, Wolfgang

Heinemann i Sven F. Sager, 658-675. Berlin/New York: de Gruyter.

Dannecker, Martin. 2000. „Sexuallwissenschaftliches Gutachten zur Sexualität“. W: Die Rechtsstellung gleichgeschlechtlicher Lebensgemeinschaften, red. Jürgen Basedow et al., 335-350. Tübingen: Mohr Siebeck.

Erläuterungen 2009= Eingetragene Partnerschaft-Gesetz $-E P G$ (2009). http://www.parlament.gv.at/PG/DE/XXIV/I/__00485/fname_172332.pdf (data dostępu 3 września 2010 r.).

Kocourek, Rostislav. 1982. La langue La langue française de la technique et de la science. Wiesbaden: Brandstetter.

Köllner, Erhard. 2001. Homosexualität als anthropologische Herausforderung: Konzeption einer homosexuellen Antropologie. Bad Heilbrunn: Klinkhardt.

Korycki, Stefan, Jerzy Kuciński, Zenon Trzciński, i Jerzy Zaborowski. 2008. Zarys prawa. Warszawa: Wydawnictwo Prawnicze Lewis Nexis.

Pawlowski, Hans-Martin. 1999. Methodenlehre für Juristen: Theorie der Norm und des Gesetzes: ein Lehrbuch. Heidelberg: Müller Verlag.

Pieńkos, Jerzy. 1993. Przektad i ttumacz we wspótczesnym świecie. Aspekty lingwistyczne i pozalingwistyczne. Warszawa: PWN.

Pieńkos, Jerzy. 1999. Podstawy juryslingwistyki. Język w prawie - Prawo w języku. Warszawa: Muza SA.

${ }^{61}$ Odnotowane różnice - występujące w sposób eksplicytny - ukazują tylko część rozbieżności. Szereg uregulowań szczegółowych zawierają inne ustawy, na które wskazują autorzy tekstów w odsyłaczach. 
Powszechna Deklaracja Praw Seksualnych. Ogólnopolski Program Zdrowia Seksualnego: www.opzs.pl (data dostępu 29 lutego 2012 r.).

Redelbach, Andrzej. 1998. Wstęp do prawoznawstwa. Toruń: Wydawnictwo Dom Organizatora.

Sadurski, Wojciech. 2011. Spór o związki partnerskie: Kto się zamachnął się na Rodzinę? Gazeta Wyborcza (wydanie online), 4.07.2011 (data dostępu 29 lutego 2012 r.).

Tokarczyk, Roman. 2008. Komparatystyka prawnicza. Warszawa: Oficyna Wolters Kluwer Polska Sp. z o o.

Zawadowski, Leon. 1951. Rzeczywisty i pozorny wptyw kontekstu na znaczenie. Sprawozdania Wrocławskiego Towarzystwa Naukowego. Wrocław: WTN.

\section{Teksty źródłowe}

Bundesgesetz über die eingetragene Partnerschaft (Eingetragene Partnerschaft-Gesetz $E P G) . \quad$ http://www.parlament.gv.at/PG/DE/XXIV/I/I_00485/fname_172330.pdf (data dostępu 3 września 2010 r.).

Bundesgesetz über die eingetragene Partnerschaft gleichgeschlechtlicher Paare

(Partnerschaftsgesetz, PartG) vom 18. Juni 2004.

http://www.admin.ch/ch/d/sr/c211_231.html (data dostępu 3 września 2010 r.). Lebenspartnerschaftsgesetz vom 16. Februar 2001 (BGBl. I S. 266). http://www.gesetzeim-internet.de/bundesrecht/lpartg/gesamt.pdf (data dostępu 3 września 2010 r.) 